\title{
PEMBINAAN MENTAL KEAGAMAAN DAN KINERJA TNI AD STUDI KASUS DI KODIM 0913/PPU KABUPATEN PENAJAM PASER UTARA PROPINSI KALIMANTAN TIMUR
}

\author{
Sri Muryani \\ Program Pasca Sarjana \\ Universitas Muhammadiyah Yogyakarta \\ E-mail: srimuryanibilqis@gmail.com
}

\begin{abstract}
Abstrak
Penelitian ini adalah penelitian kualitatif dengan instrumen kunci peneliti sendiri. Pengumpulan data diperoleh melalui observasi, wawancara dan dokumentasi. Sedang analisa data dilaksanakan secara induktif yang lebih mementingkan makna dari pada generalisasi data dengan menggunakan tiga pendekatan, yaitu pendekatan kemiliteran, psikologis dan pendekatan teologi normatif. Sumber data penelitian ini terdiri dari unsur pimpinan Kodim 0913/PPU,para Asisten,para perwira staf, seluruh prajurit serta keluarga dan masyarakat sekitar bila diperlukan. Hasil penelitian ini menunjukkan bahwa pembinaan mental prajurit TNI AD di Kodim 0913 /PPU terlaksana dengan segala ciri khas yang dilaksanakan di lingkungan militer, baik dari prosedur, metode dan teknik pelaksanaannya. Pembinaan mental yang dilaksanakan tersebut ternyata memiliki pengaruh yang baik terhadap kinerja TNI AD di Kodim 0913 /PPU. Pelaksanaan pembinaan mental di Kodim 0913/ PPU ternyata belum terlaksana dengan sempurna, masih banyak yang harus dilakukan penyempurnaan misalnya profesionalisme para pembina mental, metode pembinaan mental serta materi pembinaan mental. Dukungan pimpinan dan tradisi kemiliteran (sistem komando) yang berlaku sangat mendukung.

Kata kunci : pembinaan mental, kinerja, keagamaan.
\end{abstract}

\begin{abstract}
This research is a qualitative research with the researchers own key instruments. Data collection is obtained through observation, interviews and documentation. While the data analysis is carried out inductively with more importance than the generalization of data by using three approaches, namely the military, psychological and normative theological approaches. The data source of this research consisted of elements of the Kodim 0913 / PPU leader, the Assistants, the staff officers, all the soldiers and their families and surrounding communities when needed. The results of this study indicate that the mental training of Army soldiers at Kodim 0913 / PPU is carried out with all the special characteristics carried out in the military environment, both from the procedures, methods and techniques of their implementation. The mental training that was carried out turned out to have a good influence on the performance of the Army in Kodim 0913 / PPU. The implementation of mental coaching in Kodim 0913 / PPU apparently has not been carried out perfectly, there is still much to be done such as the professionalism of mental coaches, mental coaching methods and mental coaching materials. The support of the leadership and the military tradition (command system) that applies is very supportive.
\end{abstract}

Keywords: mental development, performance, religion.

\section{Info Artikel}

Diterima Februari 2020, disetujui Maret 2020, diterbitkan Juni 2020 


\section{PENDAHULUAN}

Mental adalah kondisi jiwa seseorang yang terpantul dalam sikap dan perilaku terhadap berbagai situasi dan kondisi.Keadaan mental seseorang sangat rentan terhadap berbagai macam gangguan baik yang datang dari dalam diri sendiri ataupun dari luar diri seseorang, terlebih pada situasi dan kondisi yang dihadapi.Pembinaan mental menjadi sangat penting bagi semua orang dan hendaknya pembinaan mental di mulai sejak dalam kandungan walaupun secara tidak langsung, terlebih untuk pmbinaan mental agama.

Mental agama hendaknya diberikan pertama kali dalam keluarga karena disanalah seseorang yang baru lahir akan mengenal untuk yang pertama kali. Keluarga juga merupakan ruang lingkup yang utama dan pertama bagi seseorang yang baru terlahir. Dalam keluarga kita mendapatkan pendididkan yang pertama ,baik pendidikan keagamaan dan pendidikan keluarga itu sendiri yang mencakup segala aspek kehidupan. Pembinaan mental keagamaan apabila di berikan dan dilakukan dalam keluarga dengan baik maka dalam kehidupan sehari-hari seseorang dalam berperilaku dan bersikap akan senantiasa menunjukkan perilaku yang baik sesuai dengan nilai agama, tata kehidupan yang ada dalam kehidupan bermasyarakat berbangsa dan bernegara.

Pendidikan keagamaan yang diberikan untuk tetap menjaga tingkat keimanan dan ketaqwaan seseorang. Secara berkesinambungan dan terus - menerus pendidikan agama harus senantiasa di berikan untuk pembinaan mental menjaga tetap pada tujuan utama peningkatan keimanan dan ketaqwaan seseorang. Dengan demikian pembinaan mental tidak berhenti sampai seseorang mencapai titik akhir dalam hidupnya.Pembinaan mental yang disampaikan hendaknya sesuai dengan tujuan yang hendak dicapai yaitu menjadi seorang insan yang berakhlaq mulia dan menjadi insan yang mampu menjadi tauladan,serta beriman dan bertaqwa kepada Allah.

\section{METODE PENELITIAN}

Jenis yang dipilih untuk penelitian ini adalah penelitian kualitatif yaitu penelitian yang bersifat atau berkarakteristik bahwa data dinyatakan dalam bentuk sewajarnya atau sebagaimana adanya (natural setting) dengan tidak merubah bentuk simbol-simbol dan angka. Sedangkan pendekatan yang digunakan peneliti adalah 
pendekatan deskriptif kualitatif yaitu penelitian yang dimaksud untuk menjelaskan fenomena atau karakteristik individu, situasi, atau kelompok tertentu secara akurat.

Terkait dengan lokasi penelitian ini dipilih Penelitian ini memilih lokasi di Kodim 0913/PPU yang berlokasi di Jalan Propinsi km 09 Nipah - Nipah Kabupaten Penajam Paser Utara Propinsi Kalimantan Timur.

Penelitian ini mengambil subyek yaitu orang-orang yang bisa memberikan informasi lisan tentang sesuatu yang ingin diketahui dalam penelitian ini, baik dari unsur pimpinan Kodim 0913/PPU ,staf Kodim ( Pasipers ), Danramil, prajurit, keluarga maupun masyarakat di sekitar Kodim 0913/PPU yang dianggap dapat memberikan informasi yang berkaitan dengan penelitian.

Metode pengumpulan data yang digunakan dalam penelitian kini ada tiga yaitu; observasi, wawancara, dan dokumentasi. Analisis data adalah proses pencarian dan pengaturan secara sistematik hasil wawancara, catatan-catatan dan bahan-bahan yang dikumpulkan untuk meningkatkan pemahaman terhadap semua hal yang dikumpulkan dan memungkinkan menyajikan apa yang ditemukan.

Selanjutnya secara lebih jelas ada tiga komponen dalam model analisa interaktif sebagai berikut:

a. Pengumpulan data

Data yang dikumpulkan akan diseleksi dan dipilih mana yang sesuai dan diperlukan pada penelitian. Data yang telah terpilih akan menjadi sumber penting dalam penelitian.

b. Penyajian data

Data yang telah terkumpul akan disusun sedemikian rupa sehingga kemungkinannya akan bisa diambil kesimpulan

c. Penarikan kesimpulan

Data yang telah dikumpulkan dan disusun kemudian dipahami dengan baik oleh penulis. Penulis mempelajari hasil dari data yang telah diperoleh kemudian diambil kesimpulan akhir dari penelitian tersebut. 


\section{HASIL DAN PEMBAHASAN}

\section{Profil Kodim 0913/PPU Kalimantan Timur}

Komando Distrik Militer atau biasa disingkat dengan Kodim adalah komenado pembinaan operasional kewilayahan. Di beberapa Kodam (Komando Daerah Militer), Kodim berada di Kabupaten atau Kota, termasuk Kodim 0913 yang berada di Kabupaten Penajam Paser Utara, Kalimantan Timur. Kodim biasanya dipimpin oleh seorang yang berpangkat Letnan Kolonel (Letkol). Pada waktu penelitian ini, Kodim 0913/PPU dipimpin oleh Letkol (Inf) Mahmud.

\section{Pembinaan Mental Islami}

Setiap kegiatan yang berhubungan dengan pendidikan, terdapat evaluasi untuk mengetahui sejauh mana efek atau pengaruh yang dirasakan dan diamalkan bagi peserta didik. Untuk bimrohis di kodim 0913/PPU Kabupaten Penajam Paser Utara, efek yang didapat dari para prajurit tersebut diukur dengan kedisiplinan mereka. Tidak ada penilaian khusus dari hasil yang didapat kecuali adanya permasalahan yang berta seperti kekerasan dalam rumah tangga bagi prajurit dan lain sebaginya. Menurut pembina, yang menjadi tolak ukur untuk mengetahui efek binroh tersebut adalah kedisiplinan. Apabila mereka tidak disiplin dalam menjalankan berbagai tugas, maka efek dari kegiatan tersebut tidak ada.

Apakah hal ini karena tema yang dibahas kurang meyakinkan dan membosankan atau memang dari prajurit tersebut tidak fokus dalam mengikuti kegiatan. Jika memang permasalah itu datang dari tema, pihak bimrohis akan lebih inovatif lagi dalam tema dan jika memang dari prajurit, akan lebih ditingkatkan kembali pendidikan yang lebih efektif.

\section{Pembinaan Mental Di tinjau Dalam Perspektif Pendidikan Islam Pada Prajurit TNI AD Kodim 0913 /PPU}

Berdasarkan observasi yang dilakukan oleh peneliti dan melakukan wawancara terhadap beberapa narasumber, bahwa perintah panglima yang menganjurkan untuk melaksanakan sholat berjam'ah, pada awal nya terasa berat. Tetapi karena faktor kebiasaan, maka yang sebelumnya terasa terpaksa menjadi ikhlas. Dan seiring dengan waktu, semakin merasakan kekhusyukan dalam melaksanakan ibadah dhuhur. Hal ini 
sesuai dengan beberapa model pembinaan di kalangan pelajar, bahwa salah satu metodologi pendidikan adalah dengan cara melakukan pembiasaan. Menurut Al Ghazali sendiri, seorang yang menginginkan akhlaq yang terpuji, maka caranya ia harus dibebani dengan akhlaq yang terpuji. Baik dengan cara riyadhah (pelatihan) maupun mujahadah (bersungguh-sungguh). Kedua konsep ini sangat dekat dengan kondisi lingkungan militer.

Menurut Kapten (Inf) Andi Supratikno, terdapat pengaruh pembinaan mental keagamaan yang diberikan kepada prestasi kerja. Dan hal ini berdampak pada pelaksanaan kegiatan. Dalam hal kedisiplinan, semakin berkurangnya pelanggaran. Sedangkan menurut Kapten Martono, Danramil, bahwa pembinaan mental keagamaan sangat berdampak positif pada prestasi dan kinerja anggota. para anggota lebih rajijn dan tidak terlambat datang, cepat dan tepat ketika mengerjakan tugas dari atasannya.

Kerukunan antar sesama anggota TNI ini memang sulit untuk diukur secara empirik. Karena tabiat permusuhan lebih banyak bersifat internal dan jarang ditunjukkan, kecuali dalam perkelahian fisik. Tetapi, berdasarkan pengamatan (observasi) dan wawancara sekedarnya, sebagian besar dari para anggota saling mengenal satu sama lainnya, dan terlihat mereka bertegur sapa. Sehingga secara kasat mata, kerukunan hidup antar anggota terjaga

Sulit untuk mengukur apa keterkaitan terjaganya kerukunan dengan pembinaan mental keagamaan. Berdasarkan wawancara penulis dengan Sertu Sadiran, Babinsa, bahwa Pembinaan Keagamaan sudah diatur, yaitu tiap apel pagi bagi para anggota dan PNS. Sedangkan untuk keluarga di minggu pertama dan ketiga, dan di acara pengajianpengajian yang sering diselenggarakan oleh Makodim. Sehingga, setidaknya para keluarga makodim bertemu sepekan sekali. Dan hampir tiap hari bagi para anggota. banyaknya intensitas pertemuan, baik antar anggota maupun antar istri anggota (persit) tanpa adanya kasus perkelahian secara fisik, maka dapat dikatakan secara umum terjaga, dan pembinaan mental rohani, mempunyai andil relatif besar dalam menciptakan kerukunan ini. 


\section{KESIMPULAN}

a. Proses Pembinaan Mental Keagamaan di Kodim 0913/PPU dilakukan oleh seksi Bintal Rohani baik dari Korem 091 ASN, Bintal Rohani Kodam VI Mulawarman dan Komandan Kodim 0913/PPU serta para Pasi di wilayah Kodim0913/PPU. Beberapa tahapan pembinaan Mental meliputi : 1) Tahapan Pengamatan, 2) Perencanaan, 3) Kegiatan, 4) Evaluasi, 5) Perbaikan. Pembinaan mental mencakup berbagai kegiatan, tidak hanya meliputi konseling. Tetapi Terdapat banyak jenis kegiatan pembinaan :1) penyajian materi, 2) ceramah/pengajia di masjid 3) diskusi/seminar. 4) Penerangan pada apel pagi dan jam Komandan. Materi pembinaan disesuaikan dengan jenis pembinaan nya.

b. Faktor pendukung maupun penghambat dalam pelaksanaan kegiatan pembinaan mental keagamaan. Faktor penghambat diantaranya adalah sering terbenturnya waktu, terdapat juga masalah internal (seperti rasa malas ataupun bosan) ketika mendengarkan ceramah keagamaan, serta faktor eksternal, seperti adanya kebiasaan menghabiskan waktu untuk hiburan karena semakin banyaknya fasilitas hiburan seperti HP \& televisi. Faktor Pendorong meliputi banyak hal. Yaitu meliputi kegiatan ini difasilitasi dan dibantu oleh Korem maupun Bintal. Banyaknya fasilitas bangunan yang bisa digunakan, serta adanya dukungan finansial untuk menyelenggarakan kegiatan bimbingan keagamaan.

c. Dari hasil yang dicapai oleh bimbingan mental keagamaan, berdasarkan wawancara peneliti dengan narasumber,semua menyatakan bahwa bimbingan mental keagamaan mempunyai pengaruh besar dalam merubah ataupun membentuk menta kegamaan anggota menjadi lebih baik. Baik itu dalam masalah keyakinan (agama), masalah kedisiplinan dan tanggungjawab.Sehingga dengan ini mampu meningkatkan kinerja anggota TNI AD di Kodim 0913/PPU.

\section{DAFTAR PUSTAKA}

Abdullah, M. Yatimin. 2007. Studi Akhlak dalam Perspektif Al Qur'an. Jakarta: Amzah.

Ahmad Janan, A., dan Asifudin, M.A. 2004. Etos Kerja Islami. Surakarta: Muhammadiyah University press.

Abdurrahman. 1998. Ilmu Pendidikan, Sebuah Pengantar dengan Pendekatan Islami. Cet1; Jakarta: PT. Al-Qushwa. 
Ali, M., dan Sayuthi. 2002. Metodologi Penelitian Agama: Pendekatan Teori dan Praktek. Ed.1, cet. 1; Jakarta: PT. RajaGrafindo Persada.

Ali., dan Ismail, S. 1995. Sumber-Sumber Pendidikann Islam, Hasan Langgulung, Beberapa Pemikiran tentang Pendidikan Islam. Cet. 10; Bandung: PT. Al-Ma'arif.

Arikunto, S. 2006. Prosedur Penelitian Suatu Pendekatan Praktik. Jakarta: Rineka Cipta.

Daradjat, Z., dkk. 1996. Ilmu Pendidikan Islam. Ed. 1, cet. 3; Jakarta: Bumi Aksara.

Daradjat, Z. 1975. Pendidikan Agama dalam Penmbinaa Mental. Jakarta: Bulan Bintang.

Departmen Pendidikan dan Kebudayaan. 1994. Kamus Besar Bahasa Indonesia. Jakarta: Balai Pustaka.

Hadi, S. 1982. Metodologi Riset. Jilid II, Yogyakarta: Andi Ofset.

Hankam/Pangab. 1974. Tentang Petunjuk Pelaksanaan Hidup Sederhana dalam Membina Mental TNI. Skep, No. Skep/579/V/1975. Jakarta : Mabes TNI.

Jalal, A. F. 1988. Asas-asas Pendidikan Islam. Cet.I; Bandung: Diponegoro.

Khaeruddin. 2002. Ilmu Pendidikan Islam, Mendesain Insan yang Hakiki dan Mengintip Muslimah dalam Sejarahnya. Ed. 1, cet. 1; Makassar: Yayasan Pendidikan Fatiya.

Moleong, L. J. 2007. Metodologi Penelitian Kualitatif. Bandung: Penerbit PT Remaja Rosdakarya. Offset.

Mabes ABRI. 1990. Himpunan Istilah Pembinaan Mental ABRI. Jakarta: Pusat Pembinaan Mental ABRI.

Mabes TNI. 2008. Naskah Departemen tentang Pola Dasar Pembinaan Mental TNI untuk Taruna Akademi TNI Tk. I Integratif Pola 12 Bulan Tahap II. Jakarta: Mabes TNI Akademi.

Mangunhardjana, A. 1986. Pembinaan Arti dan Metodenya. Yogyakarta: Kanisius.

Nizar, S. 2001. Pengantar Dasar-Dasar Pemikiran Pendidikan Islam. Cet.I; Jakarta:Gaya Media Pratama.

Soekanto, S. 2008. Pengantar Penelitian Hukum. Jakarta: Penerbit Universitas Indonesia Press.

Prijordaminto, S. 1994. Disiplin kiat menuju sukses. Pradnya Paramita. Jakarta. 